\title{
FUTURE OF PRINT AND E-NEWSPAPER IN INDIA: A CRITIQUE
}

\author{
Dr. Rusha Mudgal ${ }^{1}$, \\ ${ }^{1}$ Assistant Professor, \\ Amity School of Communication, \\ Amity University Gurugram
}

\author{
Prof. (Dr.) Pooja Rana ${ }^{2}$ \\ ${ }^{2}$ Professor, \\ Amity School of Communication, \\ Amity University Gurugram
}

Article DOI: https://doi.org/10.36713/epra4457

\begin{abstract}
Print newspapers in India have evolved over the years. The significant readership of print newspaper is an evidence of it being a popular medium among people. Newspapers in India started before independence and gained much attention during the time of freedom struggle with many revolutionaries contributing to the growth of journalism. It became an effective medium to reach the masses. Post independence, print newspapers looked forward to maintaining the newly found freedom. In 1950s, National development became primary goal for the newspapers. Newspapers, by then, had earned the reputation of being a credible source of information. They served as important link between the government and citizens. As post independence many industries were affected by the wave of commercialization, journalism was also not left unaffected. With the coming of satellite television during1990s there were speculations that print newspapers would go obsolete. But newspapers reinvented themselves and learnt to not only co-exist but also made good profits. The dawn of the digital era saw the birth of enewspapers. India too followed the suit amidst speculations that print newspapers will go obsolete but once again it reinvented itself and survived the wave of change. This paper attempts to trace the journey of newspaper from print to digital. It also attempts to prognosticate the future of print newspaper and e-newspaper in the Indian subcontinent. The paper concludes that although print newspapers are not going anywhere in the near future owing to their willingness to reinvent themselves, the future of newspaper is digital. The paper also explains the factors responsible for the shift in news consumption habits of the Indian readers. To accomplish the objectives of the study, the researchers conducted a focus group discussion with experts from media industry and academia.
\end{abstract}

KEYWORDS: Print newspapers, e-newspapers, new media, digital platforms, vernacular press, localization of news.

\section{INTRODUCTION}

The earliest form of newspaper was a daily sheet published in Rome; it was known as Acta Diurina meaning Daily Event (Joad Raymond, 1999). According to various studies, the first known print newspaper was found in Beijing. Research evidences point out that Johannes Gutenberg was the first to make use of a printing press. In $1700 \mathrm{~s}$ it thrived with promoting components. Though the oldest forms of mass media is print newspapers yet, it was never known to be old-styled during the period of its almost 400-years of existence.

Most of the historians have diverse answers on the actual date of publication of the first newspaper in the world, but it is usually accepted that the first structured attempt to offer a similar work happened in ancient Rome. The newsletters were hand written, and not printed. It informed the usual happenings in and around the capital to the widespread areas of the Roman Empire.

The earliest written news bulletins in all probability appeared in China, with a court gazette issued throughout the T'ang family (618-906 BC) and skim primarily by administration. A later important development usually cited by historians was the issuance of newsletters by the Fugger family of Federal Republic of Germany, a strong tribe of merchants and bankers within the fifteenth and sixteenth centuries.

Modern journalistic practices in Britain initiated during the nineteenth century witnessing the growth of The London Times, which was released in 1785 as The Daily Universal Register but in 1788, its title was changed (International Encyclopedia of 
Communications, The Oxford University Press, 1989, pages 179-186). In 1881, the Japanese introduced the newspaper as a means of public communication into Korea. (Altman, 1984)

Among print media, Indian print newspaper is one of the excelling print media in the world. The year 1780 marked an important event in the history of newspaper industry when the Bengal Gazette was published from Calcutta. James Augustus Hickey has acclaimed a special spot in the account Indian press because he started the first print newspaper in India from Calcutta.

The Bombay Herald came into existence in 1789 , as the first print newspaper published from Bombay. The Bombay Courier was published in the following year. An important proverb gained popularity, which said 'one can do without a cup of tea in the morning, but not without a morning newspaper'.

\section{OBJECTIVES}

1. To trace the journey of newspaper from print to digital platform.

2. To prognosticate the future of print newspaper and e-newspaper in the Indian subcontinent.

3. To study the factors responsible for the shift in news consumption habits of the Indian readers.

\section{METHODOLOGY}

To achieve the objectives of the study, researchers collected secondary data to trace the journey of newspapers in India. To understand the shift in news consumption habits of Indian readers and future of newspapers in India, researchers conducted a focus group discussion with twelve members from media industry and academia.

\section{NEWSPAPERS AND INDIAN FREEDOM MOVEMENT}

Pre independence, the newspaper was an efficient medium used by nationalists and social reformers. It was used as a medium to influence and shape the opinion of the people and to unveil social evil practices like sati, child marriages, caste system, ban on remarriage of widows, and other such inequalities which were experienced by people in those times. Raja Ram Mohan Roy, realizing the potential of newspapers, spearheaded the movements for social reforms through newspapers like Sambad Kaumudi in Bengali and Mirat-ul-Akhbar in Persian in 1822. (Nazir, P., 2011.)

The year 1857 is significant for journalism in India as the newspapers owned by Indians and British were separated and the Vernacular Press Act 1876 was passed. (Goyal, 2017). Dadabhai Naoroji, Bal
Gangadhar Tilak, Madan Mohan Malviya, Mahatma Gandhi are some of the most significant names from the history of Indian freedom struggle who connected to the masses through newspapers like Kesari, Mahratta, Harijan, Young India and many more. Newspapers acted as mouth pieces to awaken and motivate Indian citizens during freedom struggle. This was the time when newspapers gained importance in the lives of common people.

Journalists wrote in the newspapers to stimulate the society at large, socially and politically. During the British rule in India, there was strict control and censorship by the government; newspapers were not given the liberty to express opinions against the government. The rule of the East India Company was autocratic; its officers did not welcome criticism. (Eapen, 1967).

Newspapers facilitated in the surfacing of public opinion and in creation of images through robust news reporting, articulate opinions, informing the citizens and in this manner aiding public dialogue on topics of major concern. As a matter of fact, newspapers played a considerable role in the awareness of readers, molding their attitudes, choices and characteristics.

One of the objectives of a newspaper is to recognize the common sentiment and provide expression to it; an added one is to rouse among the readers a desired attitude; the next is to valiantly represent popular flaws (Mahatma Gandhi, Harijan, May 25, 1946). Newspapers attempted to present information and thorough analysis that enabled wellversed citizens to make conscientious choices in an information-saturated society.

\section{NEWSPAPERS IN THE POST INDEPENDENCE ERA}

After independence a professional approach of newspapers replaced the role of serving as a messenger. As they begun providing employment to the people; the newspaper organizations became revenue-oriented. The various technological developments taking place lead to

a readership battle. As the literacy level improved, inquisitiveness to know about the things happening in the surrounding helped newspaper to grow. During the time period of 1970s, newspapers gained the position of being an industry. To add to that, the Indian newspaper industry is among one of the largest newspaper industries in the world. It has a extensive and wealthy legacy. All through these years, the Indian newspaper industry has grown into an influential power. It informs, entertains and also educates the readers making sure that they can completely contribute in the important affairs of the country. 
After Independence, Indian newspapers went ahead practicing the function of a watchdog and also have been portraying the role of an activating agent to speed up the course of social and economic expansion in the country. Newspapers re adjusted to meet the demands of the changes in the society.

To accelerate rural development in post independence India, charge was jointly taken forward by researchers and newspapers by carrying out a few practices in development journalism. In postindependent India, development journalism was experienced in the form of projects like Project Chattera (1969), and Udayavani (1981-84). Even with these experiments, developmental journalism did not hold much success in Indian journalism. (Murthy, 2000) in his study mentioned that the Indian Press is known for its wide coverage of political news.

\section{ROLE OF NEWSPAPERS IN NATIONAL DEVELOPMENT}

In the new found freedom, newspapers were the main sources of local, national and international news. They placed their agenda for open discussions and put forth issues to be considered. Print newspapers were perceived as credible source of information. They served as an important link between the citizens and government. Transparency between government and its citizens helped build trust and stable system. Since newspapers were the key resource of distributing information, they also had the accountability to disperse relevant information on general issues of the nation or state like population planning, health, education, environment and women related issues etc. The press had the responsibility of educating the masses about the functioning of administrative, legal and other departments of the government. (Zahra Khalid \& Ahmed, 2014)

Most often, it was observed that the continued existence of newspapers was dependent on circulation and advertising. As circulation was a major factor for catching the attention of advertisements, newspapers approved of strategies to increase circulation. In this progression newspapers classified themselves as profitmaking enterprises. As per Veteran journalist Chalapati Rao (1982), the large characteristic of Indian Press was that it was an industry then, which was administered and possessed by other industries. The responsibility of newspapers changed as a response to the shifting needs of their readers and went through a lightening of news in response to other media's coverage of lifestyle, entertainment and so on.

These tasks of newspapers in national development recline in their ability to teach, manipulate, make aware and activate people through information. For Gandhi, the key to a newspaper's role in affecting social awareness was reliability and credibility. Social obligation was vital. Transparency in all its operations was indispensable to maintain its reputation (Bhattacharjee.2003).

\section{NEWSPAPERS IN THE TIMES OF SATELLITE TELEVISION}

Till the time radio and television came into existence, print newspapers enjoyed the status of being the sole news providers. The aged ideas and perceptions that a newspaper correspond to people's conscience or nation's ethos were worn out. Journalism became a profession only in name; in actuality it was functioning as an industry. To combat the challenge from another technology, newspapers reinvented themselves again. They started with changes like more localized content, more entertainment-based content through supplements and use of glossy pages to attract attention from readers. A notable development was use of advanced technology in printing and newspapers were then published in different colors.

The newspapers were very successful in encouraging the rural population to actively contribute in improvement and reawaken their hopes and quiescent common spirit.

The newspapers investigated, analyzed, interpreted and committed itself to development. Instead of a news report, it started practicing an interpretative report. This modification in newspapers made the newspaper significant to the society to position as a public institution, which strived for the welfare of the society.

\section{NEWSPAPERS IN THE AGE OF NEW MEDIA}

The World Wide Web opened new dimensions for the information flow with the advent of web resources which have become a rivulet crossing all the borders (Gul \& shah, 2008). The magnitude of enewspapers in the form of e-paper, websites and smartphone applications is increasing on the internet, as it is becoming a favorable channel for diffusion of information.

The Hindu was the first newspaper in India to launch a website in 1995. After one hundred and thirty years of its existence, the newspaper came up with the beta version of its redesigned website at beta.thehindu.com, in August 2009. This rise of enewspapers was seen as a threat to the existence of print newspapers; instead, the print newspaper has over the years established itself remarkably flexible and adaptable all through. 


\section{ISSN (Online): 2455-3662 \\ EPRA International Journal of Multidisciplinary Research (IJMR) - Peer Reviewed Journal \\ Volume: 6 | Issue: 5 | May 2020 || Journal D0I: 10.36713/epra2013 || SJIF Impact Factor: 7.032 ||ISI Value: 1.188}

\section{RESULTS: FUTURE OF PRINT AND E- NEWSPAPERS IN INDIA}

To prognosticate the future of print and e-newspapers in the current scenario and to understand the shift in news reading habits, the researchers conducted a focus group discussion. The group comprised 12 members from the media industry and academia. The experts were professionally affiliated with organizations like The Hindu, The Times Of India, CNN-IBN, Navbharat times Online, ABP News, IIMC Delhi, India Today Media Institute and more.

The highlights of the discussion are stated below:

1. Opportunities and Challenges for Newspapers

The panelists agreed that print media is facing a challenge due to the presence of e-newspapers. Although the circulation of print newspapers is decreasing in the Western countries, it has been on a rise in India. Reason for this was considered to be the relationship between literacy growth and rising readership of newspapers, especially vernacular press in India.

It was observed that surge in literacy levels in the recent decades, better income and the professed credibility of written words are some of the reasons newspapers progressed well in India. The reason newspapers began waning in the West is because choice was involved - one has to go to a newsstand and buy a copy. In India, it is delivered at the doorstep.

English language newspapers used to dominate circulation figures in the $1960 \mathrm{~s}$. The position began to alter noticeably after the 1990s. There has been exponential rise in the demand for Hindi dailies. Discussing a report from Audit Bureau Circulation (ABC) report (December 2016), the members pointed out that in 2017 three most circulated newspapers were Dainik Jagran and Dainik Bhaskar which were both Hindi dailies and were trailed by The Times of India in English language.

The panelists opined that, credibility of newspaper and less-than-credible content of other media may have also been reason for the rise of newspapers. There are some challenges to print newspapers like rising cost of newsprint, increasing internet penetration even in small towns and villages.

They also shared that in current times Print, Broadcast \& Web media supplement each other for coexistence and growth. The panel pointed out that television was growing in the $90 \mathrm{~s}$ but then came a saturation point. A similar trend may follow for enewspapers also. As technology is evolving, there will be something new. The experts noted that Indians do not want to pay much to consume news. They also raised concerns about the revenue model of newspapers which is largely based on advertisement and advised that it needs to be changed.

As there are numerous languages in India, a major concern for e-newspapers is to cover untouched areas in India. Members shared that many enewspapers were making efforts to reach regional languages news consumers like print newspapers. They appreciated that ToI news site gives an option to convert language and connect with readers which enhances the readership but it is a challenge for the readers are not well acquainted with technology. It was observed during discussion that in India print has edge over e-newspaper because people want read in detail.

E -newspaper gives advantage of expressing oneself as a reader, this held an important outcome of the discussion. During the FGD it was shared that currently most young audience do not read or watch long news stories, so in video formats also short bulletins of news stories are prepared and shared on the web.

The portability of e-newspapers was regarded as an important factor as a reason for shift in news consumption habits.

Growth of newspapers in the country is an indicator of the fact that the readership has increased and people want variety, substance and professionalism in the content. The existent challenge for the newspapers is to reach and connect with the common people, conferring their issues and opinions. Newspapers have emerged as a credible source of information for the majority of people from time to time.

2. Factors Responsible for the Shift in News Consumption Habits of the Indian Readers

Growth in newspaper readership in India depicts higher preference towards local language newspapers. A prominent change is apparent in the rural population during the past five decades as they turn out to be one of the most significant customer groups with augmented income levels and varying choices and preferences. Another reason for growth of print newspaper circulation is the coverage of local news by regional language newspapers has given circulation the much need momentum as it provided the people in the rural areas a medium to express their grievances and aspirations. Localization paved way for multi-edition newspapers where publishers accumulated national news with local news and intensified their news content variety, with supplements. The successful performance of hyper localization of news content is also credited to readers' choice to read content in their first language.

Low priced Indian newspapers are often paired with discounts or complimentary supplement/edition which rules out price as a barrier for the readers. This helps in creating brand loyalty which is often utilized 
by advertisers. While there are many websites where one can get updated news and information newspapers have adapted to the change allowing readers to read their favourite newspaper on the mobile devices. As discussed, one can access e-newspapers of India directly on laptop or mobile devices and get the same experience that one had through the print version.

The rise in print newspapers circulation in India is majorly seen among Hindi language newspapers and vernacular press. To get in touch with outsized population the Indian print newspapers put together efforts to publish in their regional languages in small towns. Keeping in view the in growth in Hindi and vernacular press, leading newspapers have started their regional-language newspapers. The English-language newspapers cater to more contented and urban readers who are more exposed to the forthcoming changes due to new media technology.

The panelists discussed that recent circulation reports of print newspapers in India show the immense clasp of Indian languages. They shared that overall circulation of the newspapers increased about 7 percent, this was largely determined by expansion of Hindi language newspapers (around 9 percent) and other language newspapers (almost 10 percent) in comparison with the large but constant English language newspapers (about 4percent).

3. Future of Print Newspapers

The focus group shared that presently they did not see any threat so long as the newspapers reinvent and innovate. They did not see them dying so soon. But citing caution, they said that print newspapers will have to accept the reality that gradually the day will come. Digitization is taking place at a fast pace. India is a large country with huge disparities. Digitization will take time but it will catch up. So it is wise to take advantage of the time gap and prepare for the digital age fully. The panelists believed that print newspaper organisations should be prepared to brace the change. The future is certainly digital (platform), they added.

Newspaper is an important tool in shaping the growth and development of any society in this modern world. In the Indian context, there are a number of means of mass communication which have been instrumental in bridging the communication gap between people that contributes to the air of awareness in a society. The newspaper industry stands out as an influential body which contributes to the development of the nation. The industry is soul of any democratic nation. Daily newspapers provide huge contribution towards the economic and industrial development of a country. Indian daily newspaper is the order of the morning for eager news hungry readers across the country. By garnering an increasing number of subscribers in the form of readers, newspapers clearly reflect the individuality of a reader and the country as well. The growth in the circulation of newspapers in the country results in the overall economic prosperity of the country, inspiring it to higher levels.

\section{SUGGESTIONS}

Based on the study, researchers suggest that print newspapers are facing challenges at present due to the outbreak of pandemic. It is suggested that opting for digital platforms to connect with the readers is a pertinent approach. Another effective way to connect with more readers is through their local languages and with more localized investigative news stories. Further studies based on consumption patterns of vernacular press in rural areas may provide more clarity.

\section{CONCLUSION}

Digital age is the latest challenge to the existence of print newspapers. The current crisis due to the pandemic has added to the worries of the print newspapers as many newspaper organizations have laid off journalists, discontinued print editions and are witnessing a dip in circulation (due to risk of spreading of virus). Over the years, print newspaper has reinvented itself to remain in the business of news but the future of newspaper reading is digital. This can be attributed to various reasons like increasing internet penetration in India and peoples' need to be constantly updated by convenient access to news. India is at the threshold of becoming the youngest nation and youth is more inclined towards the use of technology. Digital platforms undoubtedly have a bright future in India but newspapers also hold strong readership especially in regional languages. Print newspapers may not go completely obsolete in the near future but future of news consumption definitely is digital.

\section{REFERENCES}

1. Altman, A. (1984). Korea's First Newspaper: The Japanese Chōsen shinpō. The Journal Of Asian Studies, 43(4), 685-696. doi: 10.2307/2057150

2. Bhattacharjee. Ajit. (2003a). Gandhi's media Values. Vidura, 40 (2).p.21.

3. Chyi, H., \& Lasorsa, D. (1999). Access, Use and Preferences for Online Newspapers. Newspaper Research Journal, 20(4), 2-13. doi: 10.1177/073953299902000401Eveland, W. P., Marton, K., \& Seo, M. (2004). Moving beyond "Just the Facts": The Influence of Online News on the Content and Structure of Public Affairs Knowledge. Communication Research, 31(1), 82108

4. Eapen, K. (1967). Daily Newspapers in India: Their Status and Problems. Journalism Quarterly, 44(3), 520-532. doi: 10.1177/107769906704400314 
5. Goyal, S. (2017). Do you know the History of Newspaper in India. Retrieved 3 May 2020, from https://www.jagranjosh.com/general-knowledge/doyou-know-the-history-of-newspaper-in-india1496304408-1

6. Gul, D., \& shah, T. (2008). Growth and Development of Online Newspapers with Special Reference to India. Retrieved from https://www.researchgate.net/profile/DrSumeer_Gu l/publication/235966593_Grow

7. Joad Raymond (1999) The history of newspapers and the history of journalism: Two disciplines or one?,Media History, 5:2, 223-232

8. Nazir, P., 2011. Raja Ram Mohan Roy: Social Reform and Empowerment of Women. Journal of Exclusion Studies, [online] 1(2), p.1. Available at: $<$ http://www.indianjournals.com/ijor.aspx?target $=i$ jor:jes\&volume $=1$ \&issue $=2$ \&article $=006>$.

9. Peng, F., Tham, N., \& Xiaoming, H. (1999). Trends in Online Newspapers: A Look at the US Web. Newspaper Research Journal, 20(2), 52-63. doi: 10.1177/073953299902000205

10. Zahra Khalid, D., \& Ahmed, D. (2014). A Snapshot of Role of Newspapers in the Contemporary Newspeak. IOSR Journal Of Humanities And Social Science, 19(5), 06-11. doi: 10.9790/0837-19550611 